\title{
Detection of Mycobacterium tuberculosis from Clinical Samples using Different Real-Time PCR System
}

\author{
Haidar Khalid Mostafa ${ }^{1 *}$, Mohsen Hashem Risan², \\ Mohammed Al-Faham ${ }^{3}$ and M.R. Tbena ${ }^{4}$
}

\author{
${ }^{1}$ Ministry of Science and Technology, Environment and water Directorate, Food Research \\ Centre, Iraq, Baghdad, Al-Jadria \\ ${ }^{2}$ Ministry of Higher Education and Scientific Research, Nahreen University, College of \\ Science, Iraq, Baghdad, Al-Jadria \\ ${ }^{3}$ Ministry of Higher Education and Scientific Research, Baghdad University, College of \\ Medicine, Iraq, Baghdad, Bab-AlModem \\ ${ }^{4}$ Ministry of Health, Iraq National TB Control, Iraq, Baghdad, Bab-AlModem
}

*Corresponding author

\begin{tabular}{|c|}
\hline $\begin{array}{l}\text { Key w ords } \\
\text { M. tuberculosis, } \\
\text { AFB, GeneXpert }\end{array}$ \\
\hline Article Info \\
\hline $\begin{array}{l}\text { Accepted: } \\
17 \text { November } 2018 \\
\text { Available Online: } \\
10 \text { December } 2018\end{array}$ \\
\hline
\end{tabular}

\section{A B S T R A C T}

During the study period (July to December 2016) a total of 188 samples (sputum and blood from each person) have been tested in the National Reference Laboratory (NRL) at the Institute of Chest and Respiratory Diseases / Baghdad. These cases are considered as suspected pulmonary tuberculosis. This study for these 188 suspected specimens declare that, 103 $(54.78 \%)$ cases were positive using direct assay (AFB smear microscopy) and 85 (45.21\%) were considered to be negative cases by smear microscopy. Of the 103 TB patients, 88 $(85.43 \%)$ were represented as new TB cases; the others $15(14.57 \%)$ patients appeared to follow up assessment of the directly observed treatment (DOT) program. Detection of $M$. tuberculosis by real time PCR GeneXpert showed that among total 188 specimens (Suspected Group), $117(62.23 \%)$ of the specimens were positive in GeneXpert from sputum and 71 (37.76\%) negative specimens by GeneXpert. This study, declares the percentage of sensitivity, specificity, PPV and NPV of GeneXpert which were $94.11 \%, 92.75 \%, 95.72 \%$ and $90.14 \%$ respectively. Detection of $M$. tuberculosis by real time PCR using Realline kit showed that among the total 188 specimens (Suspected Group), $112(59.57 \%)$ of the specimens were positive and $76(40.4 \%)$ negative which detected by Real-Time PCR using Realline Kit. All these samples are sputum. This study showed the percentage of sensitivity, specificity, PPV and NPV of Realline kit were $92.43 \%, 97.1 \%, 98.21 \%$ and $88.15 \%$ respectively. Detection of $M$. tuberculosis by real time PCR using MTB Robogene kit showed that among the total 188 specimens (Suspected Group), 111 (59.04\%) of the specimens were positive, and 77 (40.95\%) negative specimens by using MTB Robogene kit, the samples are sputum. The sensitivity, specificity, PPV and NPV of our study was $87.3 \%, 89.85 \%, 93.69 \%$ and $80.51 \%$ respectively. Detection of $M$. tuberculosis by real time PCR using MTB- DNA Blood showed that among total 188 specimens (Suspected Group), 59 (31.38\%) were positive in PCR and 129 (68.61\%) were negative, DNA was extracted directly from blood and then tested in MTB Robogene kit. The present showed the percentage of the sensitivity, specificity, PPV and NPV to be $47.89 \%$, $97.1 \%, 96.6 \%$ and 51.93 . 


\section{Introduction}

TB is considered the deadliest bacterial infections in the world. Infection with this disease can be fatal and it has a large impact on the global health getting international attention with increasing number of cases worldwide where the developed and developing countries were critically included (WHO, 2015) MTB is the main causative agent of TB which is an aerobic pathogenic bacillus that establishes infection in the lungs. It is believed that two billion people are carrying non- eradicated intra-granulomatous Tuberculosis bacilli as LTBI (short for latent tuberculosis infection) and around $10 \%$ of those people will be infected with active tuberculosis during their lifetime (Gerald L mandell John E Bennett Raphael 2010)The MTB complex consists of: $M$. tuberculosis, $M$. canetti, M. microti, M. pinipedi, M. africanum, $M$. bovis and M. caprae most of infections in humans are caused by $M$ tuberculosis with a small number of infections caused by $M$. africanum and M. bovis (LoBue et al., 2010).

It is estimated that $1 / 3$ of the population (around 2 billion people) are infected with TB bacilli however only $5-10 \%$ of people get infected with the active disease (WHO 2007) the remaining $90 \%$ will initially be experience no symptoms of the disease and will experience latent disease which reactivation may happen the world health organization estimate that in 2008 there were 9.4 million cases of TB lead to 1.3 million deaths (WHO2009).The incidence infections and disease varies greatly geography wise as the estimated number of cases in 2008 occurred in Asia (55\%) and Africa (30\%) (WHO 2009)

Iraq is one of the 7 countries of the Region with a high infection rate of TB and has $3 \%$ of total number of cases worldwide there are and estimated number of 20000 TB patients in Iraq and more than 4000 estimated deaths due to
TB (WHO2014). Smear microscopy is the most widely used test for the diagnosis of tuberculosis (TB). The majority of laboratories use conventional light microscopy to examine Ziehl-Neelsen stained direct smears, documented to be highly specific in areas with a high prevalence of TB but with varying sensitivity (20-80\%) (WHO, 2009).A definitive diagnosis of tuberculosis can be made by culturing Mycobacterium tuberculosis organisms from a patient specimen most often sputum, but may also include pus, CSF, biopsied tissue etc. (Kumar et al., 2007). Many types of cultures are available. Traditionally, cultures have used the Lowenstein-Jensen (LJ) and Middlebrook media (7H9, 7H10, and 7H11) (Drobniewski et al., 2013).

Mycobacterial culture remains the gold standard for detection and drug susceptibility testing (DST). Traditionally, culture on an egg-based solid medium, known as Lowenstein-Jensen medium, may take as long as 4-6 weeks. Liquid culture systems by using mycobacterial growth indicator tube (MGIT) offer a more sensitive and rapid alternative to conventional solid culture and may detect growth in 1-3 weeks (Cruciani et al., 2004; Dinnes et al., 2007). The emergence and spread of multidrug resistant (MDR) and extensively drug-resistant (XDR) Mycobacterium tuberculosis complex (MTBC) strains poses significant challenges to disease control (WHO, 2010). In order to overcome conventional methods low sensitivity and diagnostic delays, nucleic acid amplification (NAA) tests have been introduced. The Xpert MTB/RIF is a cartridge based, automated diagnostic test that can identify Mycobacterium tuberculosis (MTB) and resistance to rifampicin (RIF). It was codeveloped by Cepheid, Inc. and Foundation for Innovative New Diagnostics, with additional financial support from the US National Institutes of Health (NIH) and 
technical support from the University of Medicine and Dentistry of New Jersey (UMDNJ). In December 2010, the World Health Organization (WHO) endorsed the Xpert MTB/RIF for use in TB endemic countries (WHO, 2010) and declared it a major milestone for global TB diagnosis. This followed 18 months of rigorous assessment of its field effectiveness in TB, MDR-TB and TB/HIV co-infection (Small and Pai, 2010). This test, and others that are likely to follow, have the potential to revolutionize the diagnosis of TB (Small and Pai, 2010; Van Rie et al., 2010). In 2012, Gene Xpert MTB/RIF first applied in Iraq and this first study about the using of this technique in the diagnosis of tuberculous pleural effusion. The recently introduced Xpert MTB/RMP assay detects the presence of MTB DNA and its susceptibility to rifampin (RMP) in a single reaction (Helb et al., 2010). Microbiological diagnostics is being revolutionized by realtime PCR because of the sensitivity and specificity of detection for determination of variants the sensitivity of real time PCR in clinical specimens ranges from 71.6\%-98.1\% more than conventional staining $(46.3 \%)$ and culture techniques (41.8\%) and it has a $100 \%$ mycobacteria detection specificity (Parashar et al., 2006). It is also more cost efficient than traditional culture methods in determining the quantity of a given pathogen in a clinical specimen and it takes way less time than traditional methods which take from 1-14 days where as real time PCR takes around 30-50 minutes and those results are obtained in similar or better sensitivities. Unlike traditional culture methods which focus on measuring live pathogens real time PCR can measure both live and dead pathogens (Hein et al., 2001).

The aim of this project is the molecular characterization of $M$. tuberclosis isolated from patient (Baghdad). Identification of $M$. tuberclosis basically depend on microscopic characterization and then on PCR Technique, different system and have rapid diagnostic methods, with high sensitivity and specificity Lab method to diagnose diseased patients.

\section{Materials and Methods}

\section{Patients and sample collection}

The study was conducted at National Reference Lab (NRL) of tuberculosis/ Baghdad, total of 188 patient suspected and 80 normal persons. Two samples have been gathered from every patient. first, one became taken from patient when he just reached the institute; second pattern accrued at early morning earlier than breakfast, the early morning collection represents the pulmonary secretions accrued in a single day, and consequently it typically has a better positivity. Gathered specimens were stored at $-20^{\circ} \mathrm{c}$ until use (IUATLD, 2000; Ssengooba et al., 2012). Ziehl-Neelsen stain sputum smears were tested for the presence of pulmonary acid fast bacilli. Also forty specimens from healthful men and women have been accumulated as negative control.

\section{DNA extraction using spin column (innuPREP Mycobacteria DNA Kit)}

Transfer $200 \mu \mathrm{l}$ of sputum into $1.5 \mathrm{ml}$ reaction tube (DNA_D1 which already supplied with the amplification kit MTB DNA Qualitative kit, containing Internal control DNA) and add $200 \mu \mathrm{l}$ NAC buffer. Vortex shortly and incubate the sample at room temperature under continuous shaking for 20 minutes. Centrifuge the sample at $10000 \mathrm{rpm}$ for 15 minutes. Remove the supernatant carefully, but completely. Add $200 \mu \mathrm{l}$ TE buffer to the bacterial pellet and re-suspend the pellet completely. Add $15 \mu \mathrm{l}$ Lysozym (stock solution $10 \mathrm{mg} / \mathrm{ml}$ in TE buffer). Mix by pulsed vortexing for $5 \mathrm{~s}$. Incubate at $37^{\circ} \mathrm{C}$ for 30 minutes. After lysis with lysozyme add 200 
$\mu 1$ lysis solution TLS and incubate the tube at $95{ }^{\circ} \mathrm{C}$ for 20 minutes. After incubation at 95 ${ }^{\circ} \mathrm{C}$ place the tube on ice for 2 minutes. Open the tube and add 25 ul Proteinase $\mathrm{K}$ and incubate at $50^{\circ} \mathrm{C}$ for 30 minutes. Apply $600 \mu \mathrm{l}$ of the sample to the Spin Filter (Blue) located in a $2 \mathrm{ml}$ receiver tube. Close the cap and centrifuge $12000 \mathrm{rpm}$ for 2 minutes. Discard the receiver tube with the $\mu$ filtrate. Place the spin filter into new $2 \mathrm{ml}$ receiver tube. Open the spin filter and add $500 \mu \mathrm{l}$ washing solution HS, close the cap and centrifuge $12000 \mathrm{rpm}$ for 1 minutes. Discard the receiver tube with the filtrate.

Place the spin filter into new $2 \mathrm{ml}$ receiver tube. Open the spin filter and add $650 \mu 1$ washing solution MS, close the cap and centrifuge $12000 \mathrm{rpm}$ for 1 minutes. Discard the receiver tube with the filtrate. Place the spin filter into new $2 \mathrm{ml}$ receiver tube. Centrifuge at max. Speed for 2 minutes to remove all traces of ethanol. Discard the $2 \mathrm{ml}$ receiver tube. Place the Spin Filter into $1.5 \mathrm{ml}$ Elution Tube. Carefully open the cap of the spin filter and add $50 \mu \mathrm{l}$ pre-heated Elution Buffer. Incubate at room temperature for 2 minutes. Centrifuge at $8000 \mathrm{rpm}$ for 1 minutes.

\section{Fully automated Real-Time PCR System Xpert}

Label each Xpert MTB/RIF cartridge with the sample ID. (Write on the sides of the cartridge or affix ID label.) Note: Do not put the label on the lid of the cartridge or obstruct the existing 2D barcode on the cartridge. Transfer at least $0.5 \mathrm{~mL}$ of the total resuspension pellet to a conical, screw-capped tube for the Xpert MTB/RIF using a sterile transfer pipette. Alternatively, the entire sample may be processed in the original tube. Store resuspended sediments at $2-8{ }^{\circ} \mathrm{C}$ if they are not immediately processed for Xpert MTB/RIF. Do not store for more than 12 hours. Add 1.5
mL of Xpert MTB/RIF Sample Reagent (SR) to $0.5 \mathrm{~mL}$ of resuspended sediment sample using a sterile transfer pipette and shake vigorously 10 - 20 times. Note: One backand-forth movement is a single shake.Incubate the specimen for 15 minutes at room temperature, between 5 and 10 minutes of the incubation, again shake the specimen vigorously $10-20$ times. Samples should be liquefied with no visible clumps of sputum. Particulate matter may exist that is not part of the sample. Start the test within 30 minutes of adding the sample to the cartridge.

\section{Open system Real-Time PCR qTOWER ${ }^{3}$}

Centrifuge the MTB_D4 (RoboGene® MTB DNA Qualitative Kit) briefly at full speed to collect the lyophilized Reagent Mix on the bottom of the tube. Add $200 \mu \mathrm{l}$ PCR grade water DNA to MTB_D4; close the tube, mix by brief vortexing followed by brief centrifugation at full speed.

Incubated at $37^{\circ} \mathrm{C}$ for 20 min using a thermal mixer $(800-1,000 \mathrm{rpm})$, mix by brief vortexing followed by brief centrifugation at full speed. Dissolved reagent mix can be stored at $2-8{ }^{\circ} \mathrm{C}$ and always protected from light up to 14 days (do not freeze!).

Add $20 \mu \mathrm{l}$ 1x Master Mix to sample tubes and each tube with standards. Add $5 \mu$ PCR grade water to tubes that serve as NTC and to all quantification standards containing the $1 \mathrm{x}$ Master Mix.

Do not exceed a final reaction volume of 25 $\mu 1$. Add $5 \mu \mathrm{l}$ of eluate from DNA isolation to the respective sample tubes containing the $1 \mathrm{x}$ Master Mix. Do not exceed a final reaction volume of $25 \mu 1$.

Program the applied real-time PCR platforms as indicated in Table 1 and start the program. 


\section{Results and Discussion}

\section{Population Studies}

The data set in Table 2, exhibited the percentage of infected patients were male 73 constituted (70.87) to female 33 that constituted $(32.03 \%)$, with over all male to female ratio of 2.21 (73/33) with a highly significant difference $(\mathrm{P} \leq 0.01)$. These results were in accordance with previous results reported by Shaker (2013) and Sabah (2015). The attributable for higher men incidence are poorly understood, and require additional research to identify correlating hazard agents. Difference between male and female susceptibility to TB may result partly from biological differences (i.e. sex differences), cultural and the economic state of the society cause to gender differences having access to health care. Various studies introduced evidence for a possible role of the $\mathrm{X}$ chromosome and sex hormones (i.e. testosterone) in susceptibility to TB (Neyrolles and Quintana-Murci, 2009; Bayingana et al., 2014; Boum et al., 2014). Hormones related with sex may be a compelling factor for this difference, testosterone for example decreases the macrophage activation process as well as pro-inflammatory cytokines production, on other hand estrogens are proinflammatory mediator's inducer. Recent study mentions that this difference may be due to more existence of men in the community and more an unexpected meeting with carriers and the disease's risk factors such as cigarettes and narcotic materials (Bini EI et al., 2014; Babamahmoodi et al., 2015).

\section{Extraction and concentration of DNA}

268 samples which were suspected and healthy persons underwent to deoxyribonucleic acid (DNA) extraction. The range of DNA concentrations using, MTB Robogene kit was (1.34- 13.23) $\mathrm{ng} / \mu \mathrm{l}$. The mean concentration was $7.3 \mathrm{ng} / \mu \mathrm{l}$ this value is somewhat similar to Sabah (2015) with range of DNA concentrations (1.24-12) $\mathrm{ng} / \mu \mathrm{l}$ and mean concentration $3.7 \mathrm{ng} / \mu \mathrm{l}$ (Table 3 ). The concentration of DNA was enough to successful DNA amplification when detected by real time PCR. This result was accepted in a study done by AL-Noomani et al., (2010) (Figure 1 and Table 3).

\section{Detection of $M$. tuberculosis by real time PCR GeneXpert}

The results revealed among total 188 specimens (Suspected Group), 117(62.23\%) of the specimens were positive in GeneXpert from sputum and $71(37.76 \%)$ negative specimens by GeneXpert (Table 4). Figure 2 showed the positive case and Figure 3 showed the negative case

The diagnostic of Mycobacterium tuberculosis by culture method can be accomplished in two way, one of them is solid (Lowenstein Jensen media) and another one is liquid broth system (MGIT 320). The time required to get the result by using liquid culture assay is less than the time required to get the same result by using LJ medium.

In our study, results from Lowenstein Jensen media were taken. GeneXpert characterized with very small volume and so easy to use that mean friendly user and the requirement of training is available and need low level of knowledge for the end user. The time for getting the first result is so short period only 2 hours, in another hand the result period from culture method takes very long time reach to couple of weeks (WHO, 2011, Van Rie, 2010). A lot of studies have showed the performance and advantages of GeneXpert in diagnosis of PTB (Bowles, 2011; Miller, 2011). Our study, declare the percentage of sensitivity, specificity, PPV and NPV of GeneXpert which were $94.11 \%, 92.75 \%$, $95.72 \%$ and $90.14 \%$ respectively that is comparable with other studies (Table 5) like 
the study done by (Reechaipichitkul et al., 2017) with $84 \%$ sensitivity, 92\% specificity, 91\% PPV and 85\% NPV. On account of its rapid and easy performance, the GeneXpert MTB/RIF assay has been recommended for initial testing or as an add-on to smear microscopy for TB diagnosis (Lawn et al., 2011; Van Rie et al., 2010; Opota et al., 2016). Moreover, this technique can detect resistant strains (Lin and Desmond, 2014).

Our study motivates and promotes the usage of GeneXpert in smear positive cases of pulmonary as recommended by WHO (WHO 2011)

In special cases of patients with results of smear microscopy and GeneXpert which was not clear for diagnostic pulmonary on another hands all the clinical symptoms was occur such as HIV positive, in these cases it should begin to take the treatment after positive diagnostic by using culture method
(International standard for tuberculosis care 2014) In despite of all better features of GeneXpert, this technique could not reduce the role of the traditional diagnostic assay like culture and smear and both advance and traditional works parallel as well as the antitubercular drug sensitivity should be done just to asset the development and response to the treatment and to identify resistance situation to Rifampicin for example (International standard for tuberculosis care, 2014)

\section{Detection of $M$. tuberculosis by real time PCR using Realline kit}

The results revealed among total 188 specimens (Suspected Group), 112 (59.57\%) of the specimens were positive and 76 (40.4\%) negative which detected by RealTime PCR using Realline Kit, all these samples are sputum (Table 6 and Figure 4).

Table.1 Cycling conditions for RoboGene ${ }^{\circledR}$ MTB DNA Qualitative Kit

\begin{tabular}{|l|l|l|l|}
\hline Stages & Temperature & Time & No. of cycles \\
\hline Stage $\mathbf{1}$ & $95^{\circ} \mathrm{C}$ & $10 \mathrm{~min}$. & $\mathbf{1}$ cycle \\
\hline Stage 2 & $95^{\circ} \mathrm{C}$ & $30 \mathrm{sec}$ & $\mathbf{4 5}$ cycle \\
\hline & $\mathbf{5 9}^{\circ} \mathbf{C} *$ & $\mathbf{1 : 5 0} \mathbf{~ m i n}$ & \\
\hline
\end{tabular}

Table.2 Distribution of TB patients according to their gender

\begin{tabular}{|c|c|c|c|c|c|}
\hline Gender & $\begin{array}{l}\text { Healthy } \mathrm{n} \\
(\%) \\
\mathrm{AFB} \quad- \\
\mathrm{VE}\end{array}$ & $\begin{array}{l}\text { Suspected } \\
\mathrm{n},+\mathrm{ve} \mathrm{n} \\
(\%) \text { AFB } \\
+\mathrm{ve}\end{array}$ & $\begin{array}{l}\text { Suspected } \\
\mathrm{n}, \\
\text { - ve } \mathrm{n} \\
(\%) \text { AFB } \\
+ \text { ve }\end{array}$ & $\begin{array}{l}\text { Total } n, \text { +ve } n \\
\text { (\%) AFB +ve }\end{array}$ & $\begin{array}{l}\text { Total n, -ve n } \\
(\%) \\
\text { AFB -ve }\end{array}$ \\
\hline Male & $42(100 \%)$ & $\begin{array}{l}110,73 \\
(38.8 \%)\end{array}$ & $\begin{array}{l}110,37 \\
(33.63)\end{array}$ & $152,73(48.02)$ & $152,79(51.97)$ \\
\hline Female & $\begin{array}{l}38 \\
(100 \%)\end{array}$ & $\begin{array}{l}78,30 \\
(15.9 \%)\end{array}$ & $\begin{array}{l}78,48 \\
(61.53)\end{array}$ & $\begin{array}{l}116,30 \\
(25.28)\end{array}$ & $116,86(74.13)$ \\
\hline
\end{tabular}


Table.3 DNA extraction method related with concentration and purity

\begin{tabular}{|c|c|c|c|c|}
\hline $\begin{array}{l}\text { DNA } \\
\text { extraction } \\
\text { method }\end{array}$ & $\begin{array}{l}\text { Range of } \\
\text { DNA } \\
\text { concentration } \\
\mathrm{ng} / \mu \mathrm{l}\end{array}$ & $\begin{array}{l}\text { Mean of } \\
\text { DNA } \\
\text { concentration } \\
\text { ng/ } \mu\end{array}$ & $\begin{array}{l}\text { DNA } \\
\text { Purity } \\
\text { 260/280 } \\
\text { mean }\end{array}$ & $\begin{array}{l}\text { 260/230 } \\
\text { Mean }\end{array}$ \\
\hline $\begin{array}{l}\text { MTB } \\
\text { Robogene }\end{array}$ & $1.34-13.23$ & 7.3 & 1.84 & 1.12 \\
\hline
\end{tabular}

Table.4 Distribution of TB patients according to their gender using GeneXpert

\begin{tabular}{|c|c|c|c|c|c|}
\hline Gender & $\begin{array}{c}\text { Healthy n (\%) } \\
\text { GeneXpert }\end{array}$ & $\begin{array}{c}\text { Suspected n, } \\
\text { +ve n } \\
(\%) \text { GeneXpert }\end{array}$ & $\begin{array}{c}\text { Suspected n, } \\
\text {-ve } \mathrm{n} \\
(\%) \text { GeneXpert }\end{array}$ & $\begin{array}{c}\text { Total n, +ve n } \\
(\%) \text { GeneXpert }\end{array}$ & $\begin{array}{c}\text { Total n, -ve n } \\
(\%) \\
\text { GeneXpert }\end{array}$ \\
\hline Male & $42(100 \%)$ & $110,84(76.36)$ & $110,26,(23.36)$ & $152,84(55.26)$ & $\mathbf{1 5 2 , 6 8 ( 4 4 . 7 3 )}$ \\
\hline Female & $38(100 \%)$ & $78,33(42.3)$ & $78,45,(57.69)$ & $116,33(28.44)$ & $\mathbf{1 1 6 , 8 3 ( 7 1 . 5 5 )}$ \\
\hline
\end{tabular}

Table.5 The percentage of sensitivity, specificity, PPV and NPV of GeneXpert in comparing with sputum culture

\begin{tabular}{|l|l|l|l|l|l|l|l|}
\hline GeneXpert & $\begin{array}{l}\text { L.J } \\
\text { culture } \\
+\mathrm{ve}\end{array}$ & $\begin{array}{l}\text { L.J } \\
\text { culture } \\
-\mathrm{ve}\end{array}$ & total & $\begin{array}{l}\text { Sensit } \\
\text { ivity } \\
(\%)\end{array}$ & $\begin{array}{l}\text { Specif } \\
\text { icity } \\
(\%)\end{array}$ & $\begin{array}{l}\text { PPV } \\
(\%)\end{array}$ & NPV (\%) \\
\hline GeneXpert + & 112 & 5 & 117 & & & & \\
\hline GeneXpert - & 7 & 64 & 71 & 94.11 & 92.75 & 95.72 & 90.14 \\
\hline total & 119 & 69 & 188 & & & & \\
\hline
\end{tabular}

Table.6 Distribution of TB patients according to their gender using Realline Kit in PCR

\begin{tabular}{|c|c|c|c|c|c|}
\hline Gender & $\begin{array}{c}\text { Healthy } \mathrm{n} \\
\left(\begin{array}{c}\%) \text { Realline } \\
\text { Kit }\end{array}\right.\end{array}$ & $\begin{array}{c}\text { Suspected } \mathrm{n}, \\
+\mathrm{ve} n \\
(\%) \text { Realline } \\
\text { Kit }\end{array}$ & $\begin{array}{c}\text { Suspected n, } \\
\text {-ve n } \\
(\%) \text { Realline Kit }\end{array}$ & $\begin{array}{c}\text { Total n, +ve n } \\
(\%) \text { Realline Kit }\end{array}$ & $\begin{array}{c}\text { Total n, -ve n } \\
(\%) \text { Realline Kit }\end{array}$ \\
\hline Male & $\begin{array}{c}42 \\
(100 \%)\end{array}$ & $\begin{array}{c}110, \\
75(68.18)\end{array}$ & $110,35,(31.81)$ & $152,75(49.34)$ & $\mathbf{1 5 2 , 7 7 ( 5 0 . 6 5 )}$ \\
\hline Female & $\begin{array}{c}38 \\
(100 \%)\end{array}$ & $\begin{array}{c}78,37 \\
(47.43)\end{array}$ & $78,41,(52.56)$ & $116,37(31.89)$ & $\mathbf{1 1 6 , 7 9 ( 6 8 . 1 )}$ \\
\hline
\end{tabular}


Table.7 The percentage of sensitivity, specificity, PPV and NPV of RealLine Mycobacterium tuberculosis in comparing with sputum culture

\begin{tabular}{|c|c|c|c|c|c|c|c|}
\hline RealLine TB kit & $\begin{array}{c}\text { L.J culture } \\
+\mathrm{ve}\end{array}$ & $\begin{array}{c}\text { L.J culture } \\
-\mathrm{ve}\end{array}$ & total & $\begin{array}{c}\text { Sensitivity } \\
(\%)\end{array}$ & $\begin{array}{c}\text { Specificity } \\
(\%)\end{array}$ & PPV (\%) & NPV (\%) \\
\hline $\begin{array}{c}\text { RealLine TB kit } \\
+\end{array}$ & $\mathbf{1 1 0}$ & $\mathbf{2}$ & $\mathbf{1 1 2}$ & & & & \\
\hline $\begin{array}{c}\text { RealLine } \\
\text { TB kit }-\end{array}$ & $\mathbf{9}$ & $\mathbf{6 7}$ & $\mathbf{7 6}$ & $\mathbf{9 2 . 4 3}$ & $\mathbf{9 7 . 1}$ & $\mathbf{9 8 . 2 1}$ & $\mathbf{8 8 . 1 5}$ \\
\hline total & $\mathbf{1 1 9}$ & $\mathbf{6 9}$ & $\mathbf{1 8 8}$ & & & \\
\hline
\end{tabular}

Figure.1 Genomic DNA electrophoresis extracted by MTB Kit

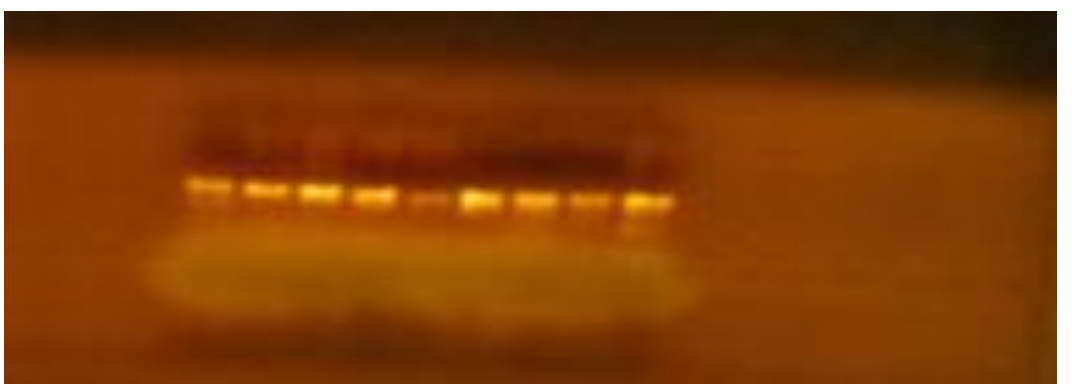

Figure.2 Positive case detected by GeneXpert

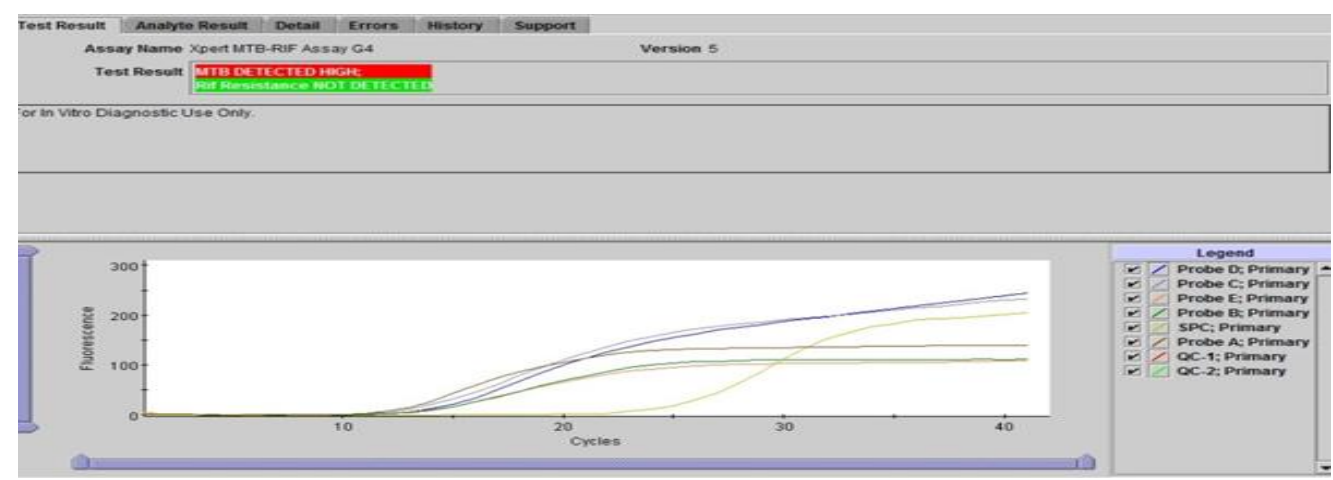

Figure.3 Negative case detected by GeneXpert

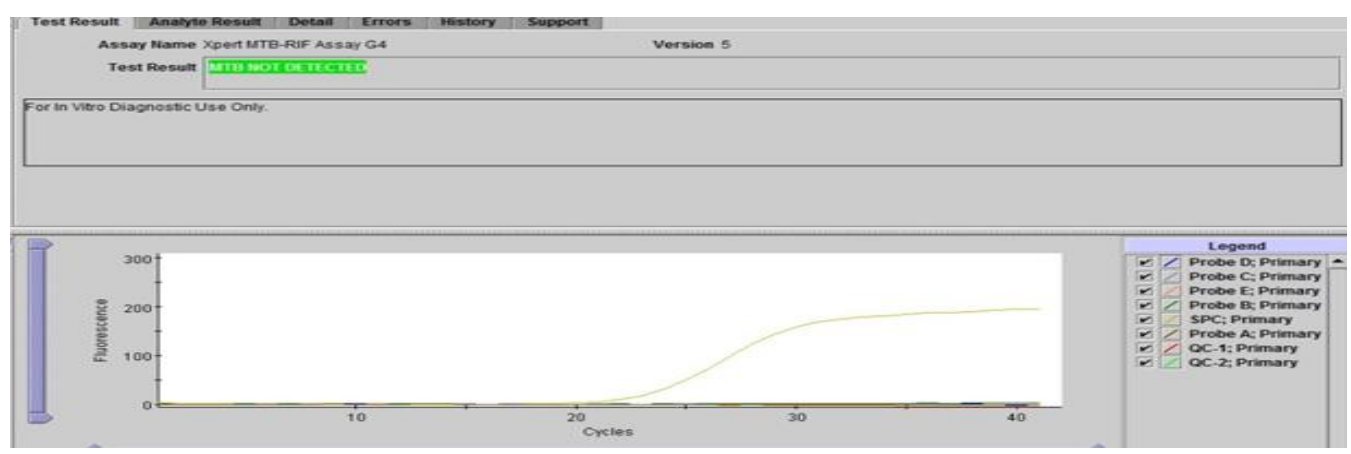


Figure.4 Positive and negative cases detected by Realline Kit

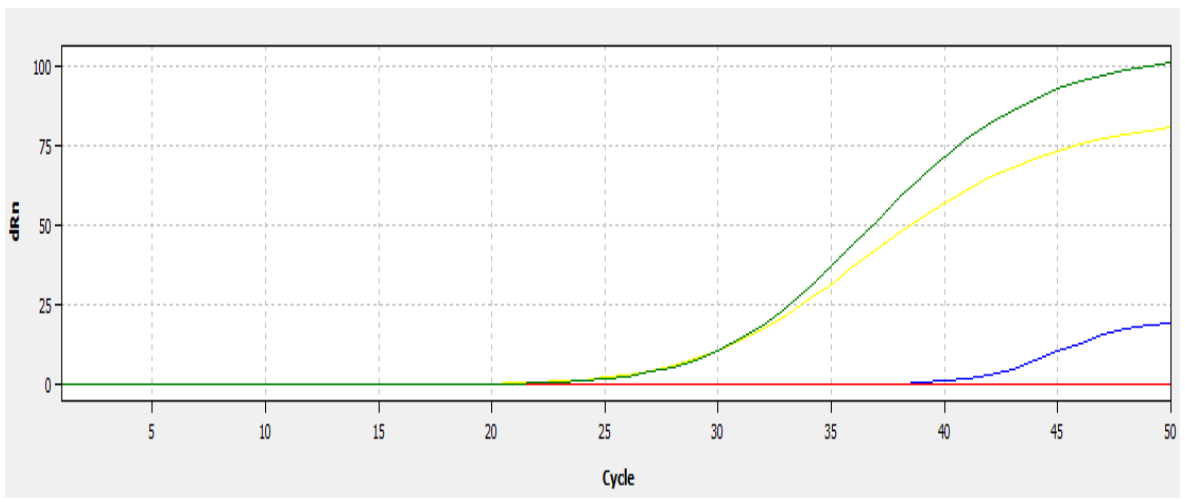

Our study showed the percentage of sensitivity, specificity, PPV and NPV of Realline kit were $92.43 \%, 97.1 \%, 98.21 \%$ and $88.15 \%$ respectively that if we compare to other studies (Table 7) is somewhat similar like the study done by (Pinhata et al., 2015) that found sensitivity of $90.3 \%$. Specificity values was $98.6 \%$ and PPV, NPV were $86.2 \%, 99.1 \%$ respectively

In this study, RT-PCR detected a higher number of confirmed TB cases in comparison with microscopy, as was also found by Nimesh et al., (2013). Moreover, RT-PCR showed high specificity, as found by Broccolo et al., (2003) and Armand et al., (2011).

It is well documented that molecular methods show good sensitivity in smear-positive samples, but are less sensitive in paucibacillary samples (Greco et al., 2006; Armand et al., 2011).

False-negative results in molecular tests can be explained by a low load of mycobacteria, the presence of polymerase inhibitors and the uneven distribution of bacilli in paucibacillary samples (Reischl et al., 1998). There were nine false-negative samples by RT-PCR in our study. It is possible that mycobacterial DNA was lost during sputum aliquoting or pre-treatment for DNA extraction.
According to Garci'a-Quintanilla et al., (2002), PCR sensitivity loss may be due to the detection of a single-copy gene (Lee et al., 2010).

\section{References}

Al-Noomani, N., Mahmoud, N., Khalil, S., and Khan, K. (2010). Clinical evaluation of real time PCR assay for detection of Mycobacterium tuberculosis DNA In Respiratory Specimens. AAMJ. 8 (3):127-142.

Armand, S., Vanhuls, P., Delcroix, G., Courcol, R., Lemaître, N.(2011). Comparison of the Xpert MTB/RIF test with an IS6110-TaqMan real-time PCR assay for direct detection of Mycobacterium tuberculosis in respiratory and nonrespiratory specimens. J Clin Microbiol. 49(5): 1772-6. doi: 10.1128/JCM.02157-10.

Babamahmoodi, F., Alikhani, A., Charati, J., Ghovvati, A., Ahangarkani, F., Delavarian, L., and Babamahmoodi, A. (2015). Clinical epidemiology and paraclinical findings in tuberculosis patients in North of Iran. BioMed Research International. vol. 2015, Article ID 381572, 5 pages. doi:10.1155/2015/381572.

Bayingana, C., Ndayisaba, P., and Mukanyangezi, M. (2014). The 
Prevalence of Tuberculosis at Butare University Teaching Hospital (Buth). Online International Interdisciplinary Research Journal. 4 (2).

Bini EI, Mata Espinosa D, Marquina Castillo $\mathrm{B}$, et al., The influence of sex steroid hormones in the immunopathology of experimental pulmonary tuberculosis. 2014; 9: e93831.

Boum, Y., Atwine, D., Orikiriza, P., Assimwe, J., Page, A., MwangaAmumpaire, J., and Bommet, $\mathrm{M}$. (2014). Male Gender is independently associated with pulmonary tuberculosis among sputum and nonsputum producers people with presumptive tuberculosis in Southwestern Uganda. BMC Infectious Diseases. 14:638

Bowles, E.C., Freyée, B., van Ingen, J., Mulder, B., Boeree, M.J., van Soolingen, D.Xpert MTB/RIF®, a novel automated polymerase chain reaction-based tool for the diagnosis of tuberculosis (2011). Int J Tuberc Lung Dis. 15(7):988-9. doi: 10.5588/ijtld.10.0574.

Broccolo, F; Scarpellini, P., Locatelli, G., Zingale, A., Brambilla, A.M., Cichero, P., Sechi, L.A., Lazzarin, A., Lusso, P., Malnati, M.S. (2003). Rapid diagnosis of mycobacterial infections and quantitation of Mycobacterium tuberculosis load by two real-time calibrated PCR assays. J Clin Microbiol. 41(10):4565-72.

Cruciani, M. Scarparo, C. and Malena, M. (2004). Meta-analysis of BACTEC MGIT 960 and BACTEC 460 TB, with or without solid media, for detection of mycobacteria. J Clin Microbiol. 42: 2321-2325.

Dinnes, J. Deeks, J. and Kunst, H. (2007). A systematic review of rapid diagnostic tests for the detection of tuberculosis infection. Health Technol Assess. 11:
191-196.

Drobniewski, F., Nikolayevskyy, V., Maxeiner, H., Balabanova, Y., Casali, N., Kontsevaya, I., and Ignatyeva, O. (2013). Rapid diagnostics of tuberculosis and drug resistance in the industrialized world: clinical and public health benefits and barriers to implementation. BMC Medicine. 11:190.

García-Quintanilla, A., González-Martín, J., Tudó, G., Espasa, M., Jiménez de Anta, M.T. (2002) Simultaneous identification of Mycobacterium genus and Mycobacterium tuberculosis complex in clinical samples by 5'exonuclease fluorogenic PCR.J Clin Microbiol. 40(12):4646-51.

Greco,S., Girardi,E., Navarra,A., Saltini, C. (2006). Current evidence on diagnostic accuracy of commercially based nucleic acid amplification tests for the diagnosis of pulmonary tuberculosis. Thorax. 61(9): 783-790.

Hein, I., Klein, D., Lehner, A., Bubert, A., Brandl, E., and Wagner, M. (2001). Detection and quantification of the iap gene of Listeria monocytogenes and Listeria innocua by a new real-time quantitative

Helb, D. Jones, M. and Story, E. (2010). Rapid detection of Mycobacterium tuberculosis and rifampin resistance by use of on-demand, near-patient technology. J. Clin. Microbiol.48 (1): 229-237.

IUATLD (2000). Sputum Examination for Tuberculosis by Direct

Kumar, V. Abbas, A. K. Fausto, N. and Mitchell, R. N. (2007). Robbins Basic Pathology (8th ed.). Saunders Elsevier. 516-522 pp. Labbafinejad, Y., Seyedmehdi, S., Nojomi, M., and Attarchi, M. (2013). Correlation between Silica Exposure and Risk of Tuberculosis in Lorestan Province of 
Iran. Tanaffos. 12(2): 34-40.

Lawn, S.D. and Nicol, M.P. (2011). Xpert MTB/RIF assay: development, evaluation and implementation of a new rapid molecular diagnostic for tuberculosis and rifampicin resistance. Future Microbiol. 6 (9): 1067-1082

Lee, E. S., Park, C.M., Goo, J.M., Yim, J.J., Kim, H.R., Lee, H.J., Lee, I.S., Im, J.G. (2010). Computed tomography features of extensively drug-resistant pulmonary tuberculosis in non-HIVinfected patients. J Comput Assist Tomogr. 34(4): 559-63. doi: 10.1097/RCT.0b013e3181d472bc.

Lin, S.Y., Desmond,E.P. (2014). Molecular diagnosis of tuberculosis and drug resistance. Clin Lab Med. 34(2):297314. doi: 10.1016/j.cll.2014.02.005.

LoBue, P. A., D. A. Enarson, and C. O. Thoen, 2010: Tuberculosis in humans and animals: an overview. Int. J. Tuberc. Lung Dis. 14, 1075-1078

Mandell, Gerald L. Bennett, John E. (John Eugene). Dolin, Raphael. 2010. Principles and practice of infectious diseases.

Melissa, B., Miller, E. B., Popowitch, M. G., Backlund, E. Performance of Xpert MTB/RIF RUO Assay and IS6110 Real-Time PCR for Mycobacterium tuberculosis Detection in Clinical Samples. (2011) J Clin Microbiol. 49(10): 3458-3462.

Neyrolles, O., and Quintana-Murci, L. (2009). Sexual Inequality in Tuberculosis. PLoS Medicine. 6 (12): e1000199.

Nimesh, M., Joon, D., Pathak, A.K., Saluja, D. (2013). Comparative study of diagnostic accuracy of established PCR assays and in-house developed sdaA PCR method for detection of Mycobacterium tuberculosis in symptomatic patients with pulmonary tuberculosis. J Infect. 67(5):399-407. doi: 10.1016/j.jinf.2013.06.015. Epub
2013 Jul 16.

Opota, O., Senn, L., Prod'hom, G., MazzaStalder, J., Tissot, F., Greub, G., Jaton, K. (2016). Added value of molecular assay Xpert MTB/RIF compared to sputum smear microscopy to assess the risk of tuberculosis transmission in a low-prevalence country. Clin Microbiol Infect. 22(7):613-9. doi: 10.1016/j.cmi.2016.04.010. Epub 2016 Apr 29.

Parashar, D., Chauhan, D., Sharma, V., and Katoch, V. (2006). Applications of real-time PCR technology to mycobacterial Research. Indian J Med Res. 124:385-398.

Pinhata, J.M., Cergole-Novella, M.C., Moreira, S. C. A., Ruivo, F. S. Rapid detection of Mycobacterium tuberculosis complex by real-time PCR in sputum samples and its use in the routine diagnosis in a reference laboratory. (2015) J Med Microbiol. 64(9):1040-5. doi: 10.1099/jmm.0. 000121.

Reechaipichitkul, W., Suleesathira, T., Chaimanee, P. Comparison of GeneXpert MTB/RIF assay with conventional afb smear for diagnosis of pulmonary tuberculosis in Northeastern Thailand. (2017). Southeast Asian J Trop Med Public Health. 48(2): 313-21.

Reischl, U., Emler, S., Horak, Z., Kaustova, J., Kroppenstedt, R.M., Lehn, N., Naumann, L. (1998). Mycobacterium bohemicum sp. nov., a new slowgrowing scotochromogenic mycobacterium. Int $\mathbf{J}$ Syst Bacteriol. $48 \mathrm{Pt}$ 4:1349-55.

Sabah, S. (2015). Genotyping and antibiotyping of Mycobacterium tuberculosis Ph.D. Thesis, College of Science, University of Baghdad.

Shaker, H. (2013). A study on diagnosis \& multidrug resistance (MDR) of 
Mycobacterium tuberculosis using different methods. M.Sc. Thesis, College of Science, University of Baghdad.

Small, P. M. and Pai, M. (2010). Tuberculosis diagnosis - time for a game change. $\mathrm{N}$. Engl. J. Med. 363: 1070-1071.

Ssengooba, W., Kateete, D., Wajja, A., Bugumirwa, E., Mboowa, G., Namaganda, C., Nakayita, G., Nassolo, M., Mumbowa, F., Asiimwe, B., Waako, J., Verver, S., Musoke, P., Mayanja-Kizza, H., and Joloba, M. (2012). An Early Morning Sputum Sample Is Necessary for the Diagnosis of Pulmonary Tuberculosis, Even with More Sensitive Techniques: A Prospective Cohort Study among Adolescent TB-Suspects in Uganda. Tuberculosis Research and Treatment. vol. 2012, Article ID 970203, 6 pages doi:10.1155/2012/97020

Van Rie, A. C. Menezes, L. Scott, K. Mellet, N. Gous, M.A. John, M. Mkhwanazi, L. Page-Shipp, W. Stevens and Sanne, I. (2011). High yield, sensitivity and specificity of Xpert MTB/RIF for M. tuberculosis detection in fine needle aspirates from $\mathrm{HIV}$-infected $\mathrm{TB}$ suspects; Program and abstracts of the 18th Conference on Retroviruses and
Opportunistic Infections; Boston, MA, USA. 2011; Abstract \#879.

Van Rie, A., Page-Shipp, L., Scott, L., Sanne, I. and Stevens, W. (2010). Xpert MTB/RIF for point-of-care diagnosis of TB in high-HIV burden, resourcelimited countries: hype or hope? Expert Rev. Mol. Diagn. 10: 937-946.

Van Rie, A., Page-Shipp, L., Scott, L., Sanne, I. and Stevens, W. (2010). Xpert MTB/RIF for point-of-care diagnosis of TB in high-HIV burden, resourcelimited countries: hype or hope? Expert Rev. Mol. Diagn. 10: 937-946.

WHO (2007). Global Tuberculosis Report 2007. World Health Organization

WHO (2009). Global Tuberculosis Report 2009. World Health Organization

WHO (2010). Multidrug and extensively drug-resistant TB (M/XDR-TB): 2010 global report on surveillance and response. World Health Organization. Geneva, Switzerland.

WHO (2011). Global tuberculosis control 2011.World Health Organization, Geneva, Switzerland.

WHO (2014). Global Tuberculosis Report 2014. World Health Organization

WHO (2015). Global Tuberculosis Report 2014. World Health Organization

\section{How to cite this article:}

Haidar Khalid Mostafa, Mohsen Hashem Risan, Mohammed Al-Faham and Tbena, M.R. 2018. Detection of Mycobacterium tuberculosis from Clinical Samples using Different Real-Time PCR System. Int.J.Curr.Microbiol.App.Sci. 7(12): 2357-2368.

doi: https://doi.org/10.20546/ijcmas.2018.712.267 